\title{
Investing in Gold: Good or Bad Choice? 20-Year History
}

\author{
Martin KRÁL 1, * and Anna OLSZAŃSKA 2 \\ 1 University of Hradec Králové, Hradec Králové, Czech Republic; martin.kral.2@uhk.cz \\ 2 Wroclaw University of Economics and Business, Wrocław, Poland; anna.olszanska@ue.wroc.pl \\ * Correspondence: martin.kral.2@uhk.cz
}

\begin{abstract}
In times of prosperity and economic growth, many people can save part of their income. At the same time, people are increasingly considering where to put their savings. Perhaps the most important factor in this is appreciation rate - while in bank accounts these interest rates do not exceed the level of inflation, alternative forms of investment may offer higher appreciation rates. The aim of this paper is to assess the benefits of investing in physical gold in the period from 2000 to 2019. It turns out that although investing in gold is referred to as long-term, and hedging rather than investment, the opposite is true. In the last twenty years, there have been only a small number of cases where an investor would not profit by buying in gold. In the vast majority of cases, it would reach an average annual appreciation of around $9 \%$ p.a., except for only a few years, when the gold price reached its maximum values. Generally, it can be stated that if an investor does not have enough information and does not want to entrust his / her savings to investing with the bank, purchasing physical gold will not make a mistake with a few exceptions. This exception is mostly easy to recognize - everyone will know that the price of gold reaches new maximum values.
\end{abstract}

Keywords: gold; investment; stock market; investor

JEL Classification: E22; E44; G51

\section{Introduction}

The basic prerequisite in economic theory is maximizing consumer's utility. Expenditures incurred by consumers on consumer goods utility almost immediately as they usually consume these goods immediately. In many cases, however, the consumer does not spend all his income on the purchase of consumer goods but saves some part, which creates just savings - investments.

When investing, however, the assumption of maximizing consumer utility remains. The goal of any rational person is profit or return on investment. However, when deciding where to deposit (invest) available cash, not only profit or appreciation rates, but also liquidity and risk are taken into account. Liquidity can be understood as the ability to convert assets into money quickly and without significant losses, while any asset that is liquid is also easily traded. Risk then expresses the risk of not achieving the expected results (returns), in the investment environment can distinguish the basic types of risks, which are inflationary risk (causing a decrease in purchasing power of investment), interest (causing market), liquidity risk (insufficient market demand for the asset), currency risk (depreciation of the currency in which the investment is held), and market risk (eg changing trading conditions for different types of assets).

Current time is characterized by the possibility of choosing from a large number of different assets that can serve as investments, but this has not been the case in the past. Gold and silver served as money because coins were made of them (Green 2007). Because precious metals initially served as a tool of exchange, their tenure was more similar to today's form of savings. Given that in ancient Greece interestrate lending, as well as the accumulation of assets, were not considered natural and philosophically correct, the only way to increase the wealth of the people at that time was to purchase other real assets.

A few thousand years later, however, people broke free from gold and silver as money. Precious metals began to be considered too rare to be paid for goods of common consumption, so they began to 
be replaced by other metals, later paper money and nowadays deposit (virtual) money. The advantage of this "modern" money is the speed of payment - for example, a payment card transaction is settled immediately, even over long distances (Svobodová and Hedvičáková 2015). On the contrary, their potential disadvantage and at the same time the common feature is that they are not covered by any real assets (such as the aforementioned gold or silver), which leads to an ever-greater decrease in their purchasing power over time (Rejnuš, 2016). In the first half of the 20th century, the US dollar was covered by gold. This meant that anyone at that time could come to the bank and demand a certain amount of gold of a predetermined value for the paper bill. So there was a gold standard, but several times the dollar was artificially changed against gold. The reason was that the dollars were printed much more than the amount of reserve gold available. In 1971, the exchange rate of 1:35 ( $\$ 35$ per 1 oz of gold) became unsustainable for the US, because European countries, led by France, began to demand gold from the US in exchange for "war" dollars. Following a dramatic decline in gold reserves, President Richard Nixon abolished the convertibility of the dollar into gold, leaving a period of open fiat currencies. Since then, gold has become a real investment in modern concepts that is durable, versatile and easily convertible, divisible, and at the same time is a store of value (Worthington and Pahlavani 2007).

\section{Methodology}

This paper aim is to analyze when in the last 20 years and at what investment horizon the investment in gold was profitable for the investor.

The first part describes the development of world gold mining. These are annual data for the period from 1700 to 2018. At the same time, countries with a significant share in the world gold mining are identified and gold reserves compared with the development of the human population. Interestingly, the proportion of gold per person in the world is also calculated. Data from internet portals that specialize in gold mining and gold prices and population data are used in the analysis.

In the second part, there is an analysis of the development of the price of gold from 1800 to 2019. The price is given in dollars per troy ounce and it is average of average closing daily price. This part is then more focused on the history of the last twenty years (ie 2000-2019). For this period, the appreciation rate of gold (i) for each year is calculated according to the formula:

$$
i=\sqrt[t]{\frac{F V}{P V}}-1
$$

where future value $F V$ denotes the future price of gold, present value $P V$ the current price of gold and $t$ the investment horizon (number of years). This appreciation rate is calculated for all years in the period 2000-2019, and for investment horizons of 1-20 years. The result, therefore, allows comparisons in which of the last 20 years the investment in gold has been the most profitable and for how long it has paid off to buy gold.

\section{Results}

\subsection{Development of world gold mining}

In ancient times, gold mining was carried out manually and it was relatively inefficient. This fact is confirmed by data - until the mid of 19th century, the volume of annual gold mined represented only units, a maximum of tens of tons. With the advent of the Industrial Revolution, the volume of mined gold increased and since 1900 it has been at least 500 tons each year. The significant decline in mining was recorded during World War II. For example, in 1945, the annual volume of mined gold was 640 tonnes, a decrease of more than 50\% compared to 1940, where a total of 1283 tonnes was mined (Our World in Data 2019). The development of gold production is shown in Figure 1: 


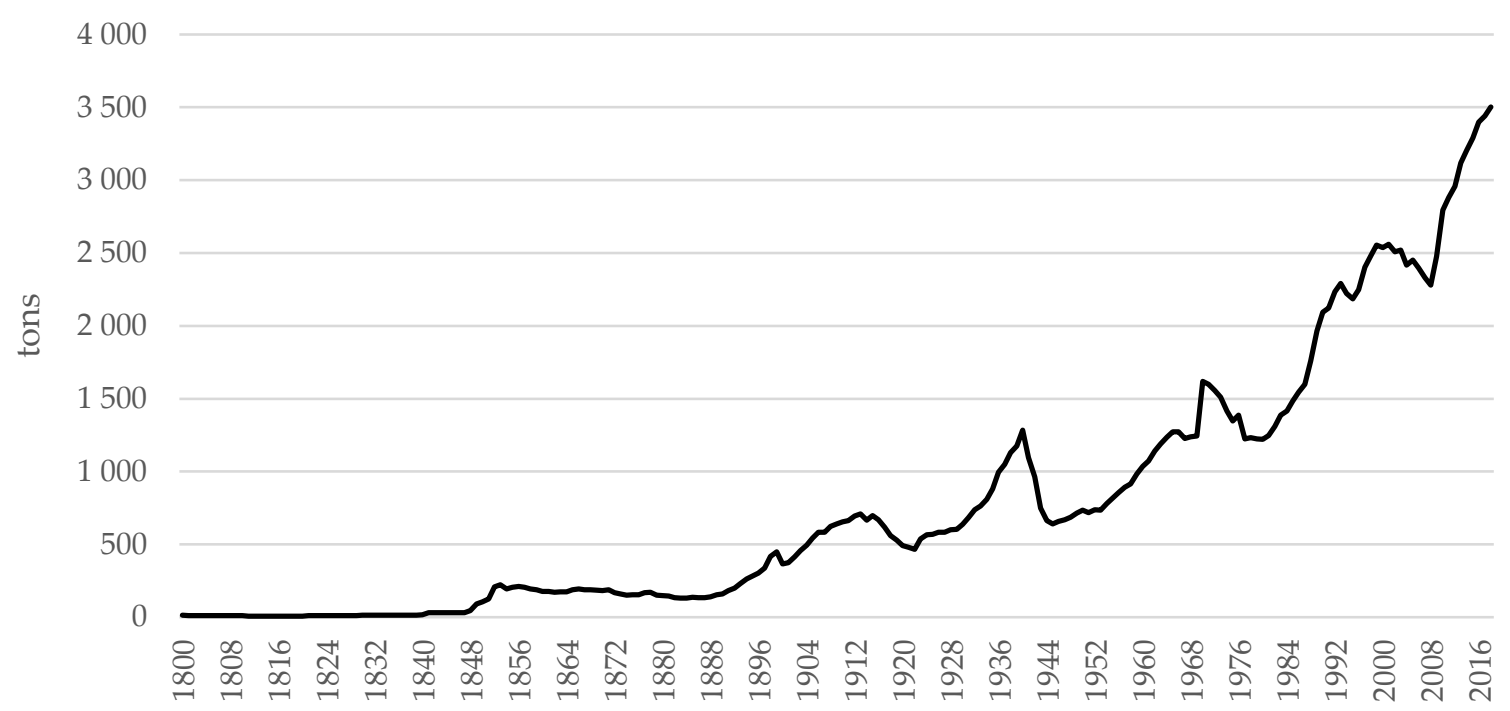

Figure 1. Gold production in tons per year, own processing based on (Our World in Data 2019; Gold Hub 2019).

Gold production has increased dramatically in the last ten years. Thus, the supply of gold has increased, which has been and still is counteracting the dramatic rise in its price that could be expected in connection with the stimulation of the economy through quantitative easing. While a total of 2,794 tons of gold was mined in 2010, eight years later in 2018 it was already 3,503 tons of gold (Gold Hub 2019). The total volume of gold production is increasing by an exponential trend, as does the human population, see Figure 2:

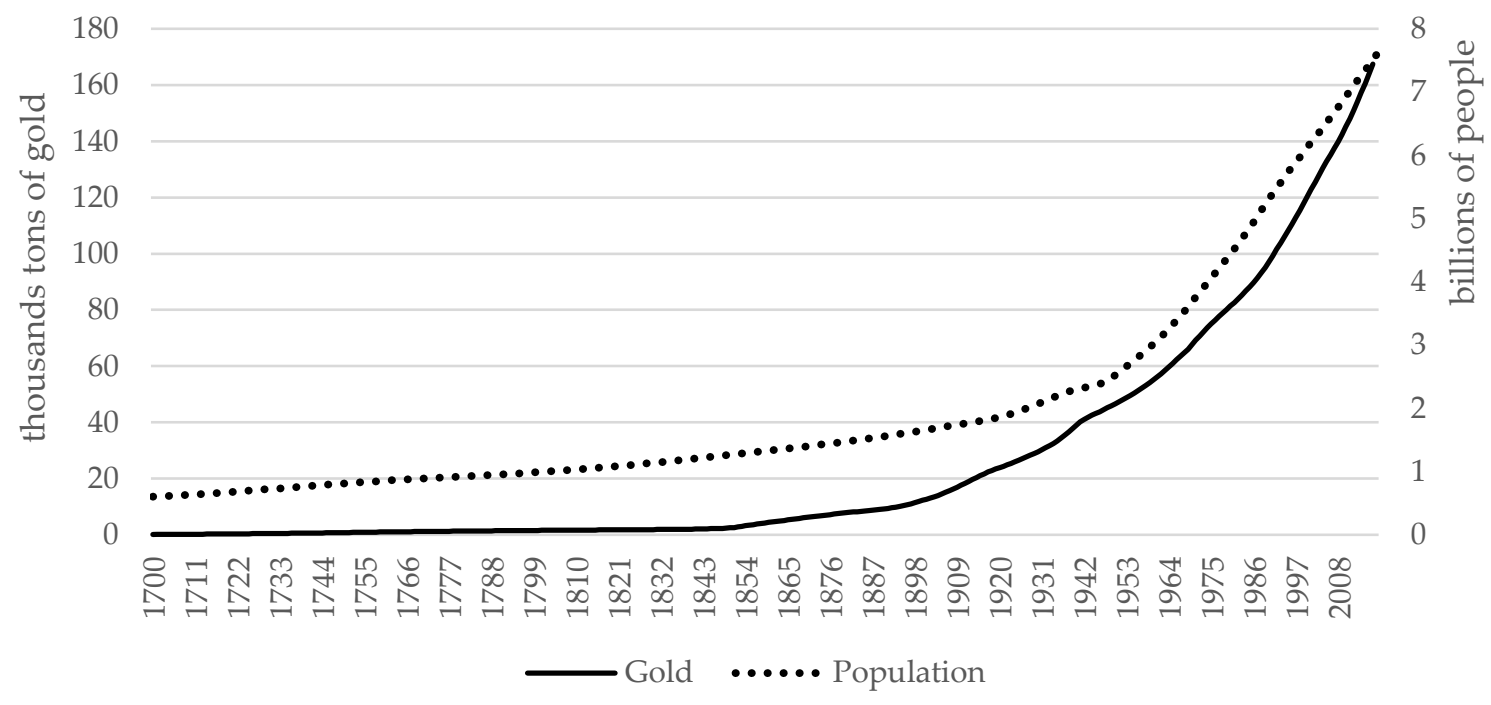

Figure 2. Gold mined - cumulative (thousands tons) in context with population development since 1681, own processing based on (Our World in Data 2019; Gold Hub 2019; World Bank 2019).

By 2018, South Africa had the largest share of the world's gold production, with almost 53,000 tons of gold being mined, followed by the United States of America with 19,000 tonnes and Australia with 14,388 tonnes (see Table 1). In recent years, it can be stated that the largest countries such as China, Russia, the USA, Canada, and Australia have the largest share in the current world gold production. However, these numbers are treacherous, a very substantial share is also represented by smaller countries, for example in Africa or South America. Because these countries are developing countries where labor costs are relatively low compared to the other countries in the developed world, this is also reflected in the mining costs and hence the final price of gold (see below). 
Table 1. Gold mined until 2018 in selected countries, own calculation based on (Our World in Data 2019; Gold Hub 2019; World Bank 2019).

\begin{tabular}{|c|c|c|c|c|c|}
\hline Country & $\begin{array}{l}\text { Gold mined } \\
\text { (tons) }\end{array}$ & Country & $\begin{array}{l}\text { Gold mined } \\
\text { (tons) }\end{array}$ & Country & $\begin{array}{l}\text { Gold mined } \\
\text { (tons) }\end{array}$ \\
\hline South Africa & 52,735 & China & 8,646 & Mexico & 3,255 \\
\hline United States & 19,086 & Uzbekistan & 4,683 & Colombia & 2,966 \\
\hline Australia & 14,388 & Peru & 4,030 & Indonesia & 2,879 \\
\hline Russia & 11,522 & Brazil & 3,680 & Papua New Guinea & 2,305 \\
\hline Canada & 11,424 & Ghana & 3,472 & Zimbabwe & 2,059 \\
\hline
\end{tabular}

It is clear, however, that the exponential trend in gold mining will not continue indefinitely and is only a matter of time before gold mining begins to slow down. However, due to similarly exponential development of the total human population, the share of gold per capita remains at about the same level and is $0.79 \mathrm{oz}$ (24.57 grams):

Table 2. Gold per person (troy ounces), own calculation based on (Our World in Data 2019; Gold Hub 2019; World Bank 2019).

\begin{tabular}{cccccccccc}
\hline $\mathbf{2 0 0 0}$ & $\mathbf{2 0 0 1}$ & $\mathbf{2 0 0 2}$ & $\mathbf{2 0 0 3}$ & $\mathbf{2 0 0 4}$ & $\mathbf{2 0 0 5}$ & $\mathbf{2 0 0 6}$ & $\mathbf{2 0 0 7}$ & $\mathbf{2 0 0 8}$ & $\mathbf{2 0 0 9}$ \\
\hline 0.69 & 0.70 & 0.70 & 0.71 & 0.71 & 0.72 & 0.72 & 0.73 & 0.73 & 0.73 \\
\hline & & & & & & & & & \\
$\mathbf{2 0 1 0}$ & $\mathbf{2 0 1 1}$ & $\mathbf{2 0 1 2}$ & $\mathbf{2 0 1 3}$ & $\mathbf{2 0 1 4}$ & $\mathbf{2 0 1 5}$ & $\mathbf{2 0 1 6}$ & $\mathbf{2 0 1 7}$ & $\mathbf{2 0 1 8}$ & \\
\hline 0.74 & 0.74 & 0.75 & 0.76 & 0.76 & 0.77 & 0.78 & 0.79 & 0.79 & \\
\hline
\end{tabular}

\subsection{Investments in Gold}

Given the ever-increasing gold production, one might expect its price to fall. This could be supported by the fact that nowadays the investor can invest his money in many alternative investment instruments or real assets. However, if we look at historical gold prices, we find that in the last 20 years, its average closing price has risen from less than $\$ 280$ per $1 \mathrm{oz}$ in 2000 to $\$ 1,391.8$ in 2019. So it was a more than five-fold increase in its price. However, it was not a constant increase, and during these 20 years there was also a significant decrease between 2012 - 2015:

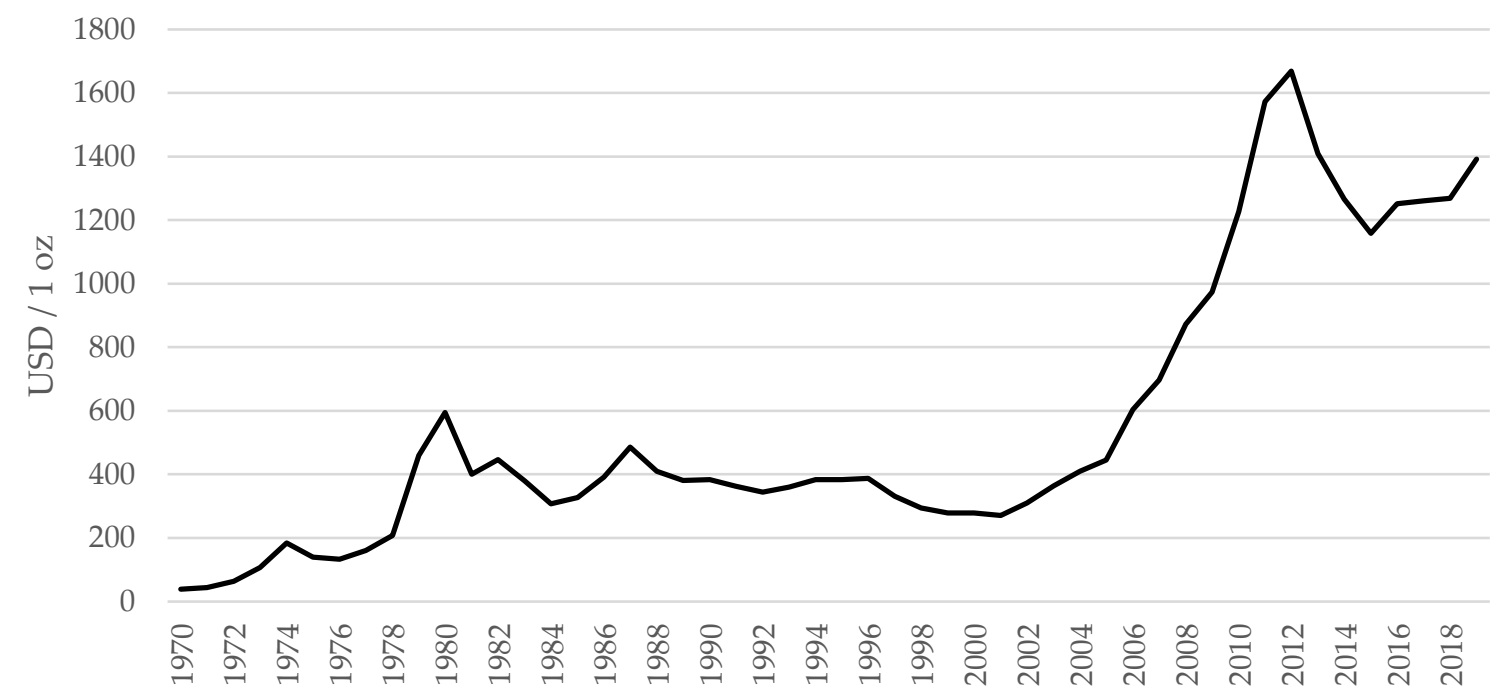

Figure 3. Gold price (USD per oz), own processing based on (Macrotrends 2019a). 
However, a retail (small) investor does not have, nor can he have perfect information (Soukal and Draessler 2012) based on which he can determine with certainty the future development of the gold price. His investment is, therefore, like any other, exposed to the risk of loss, but this loss can be eliminated if the investment horizon is extended, as in the case of shares, for example. One example is the bear market period between 2012 and 2015 when the price of gold fell from about $\$ 1670$ per $1 \mathrm{oz}$ to $\$ 1158$ per $1 \mathrm{oz}$. This was a decrease of around $30 \%$. However, such an investor would have to wait another 2-3 years and the price of his gold would reach the parallel level as in 2012.

The resulting appreciation of the "gold" investment over the last 20 years is shown in the following Table 3. For each year since 2000, the appreciation according to the above formula (1) is calculated. These values can be compared with the appreciation of other investments or even with the interest rate on savings accounts in banks.

Table 3. Appreciation of gold in 1 - 10 years since 2000 (p. a.).

\begin{tabular}{|c|c|c|c|c|c|c|c|c|c|c|c|}
\hline \multirow{2}{*}{ Year } & \multirow{2}{*}{ Price } & \multicolumn{10}{|c|}{ Length of investment (years) } \\
\hline & & 1 & 2 & 3 & 4 & 5 & 6 & 7 & 8 & 9 & 10 \\
\hline 2000 & 279.3 & $-2.9 \%$ & $5.4 \%$ & $9.2 \%$ & $10.0 \%$ & $9.8 \%$ & $13.7 \%$ & $13.9 \%$ & $15.3 \%$ & $14.9 \%$ & $15.9 \%$ \\
\hline 2001 & 271.2 & $14.3 \%$ & $15.8 \%$ & $14.7 \%$ & $13.2 \%$ & $17.4 \%$ & $17.0 \%$ & $18.2 \%$ & $17.3 \%$ & $18.3 \%$ & $19.2 \%$ \\
\hline 2002 & 310.1 & $17.3 \%$ & $14.9 \%$ & $12.8 \%$ & $18.2 \%$ & $17.6 \%$ & $18.8 \%$ & $17.8 \%$ & $18.8 \%$ & $19.8 \%$ & $18.3 \%$ \\
\hline 2003 & 363.8 & $12.6 \%$ & $10.6 \%$ & $18.4 \%$ & $17.6 \%$ & $19.1 \%$ & $17.8 \%$ & $19.0 \%$ & $20.1 \%$ & $18.4 \%$ & $14.5 \%$ \\
\hline 2004 & 409.5 & $8.7 \%$ & $21.5 \%$ & $19.4 \%$ & $20.8 \%$ & $18.9 \%$ & $20.1 \%$ & $21.2 \%$ & $19.2 \%$ & $14.7 \%$ & $11.9 \%$ \\
\hline 2005 & 445.0 & $35.8 \%$ & $25.1 \%$ & $25.2 \%$ & $21.6 \%$ & $22.5 \%$ & $23.4 \%$ & $20.8 \%$ & $15.5 \%$ & $12.3 \%$ & $10.0 \%$ \\
\hline 2006 & 604.3 & $15.2 \%$ & $20.1 \%$ & $17.2 \%$ & $19.4 \%$ & $21.1 \%$ & $18.4 \%$ & $12.9 \%$ & $9.7 \%$ & $7.5 \%$ & $7.6 \%$ \\
\hline 2007 & 696.4 & $25.3 \%$ & $18.2 \%$ & $20.8 \%$ & $22.6 \%$ & $19.1 \%$ & $12.5 \%$ & $8.9 \%$ & $6.6 \%$ & $6.7 \%$ & $6.1 \%$ \\
\hline 2008 & 872.4 & $11.6 \%$ & $18.6 \%$ & $21.7 \%$ & $17.6 \%$ & $10.1 \%$ & $6.4 \%$ & $4.1 \%$ & $4.6 \%$ & $4.2 \%$ & $3.8 \%$ \\
\hline 2009 & 973.7 & $26.0 \%$ & $27.1 \%$ & $19.7 \%$ & $9.7 \%$ & $5.4 \%$ & $2.9 \%$ & $3.7 \%$ & $3.3 \%$ & $3.0 \%$ & $3.6 \%$ \\
\hline 2010 & $1,226.7$ & $28.2 \%$ & $16.6 \%$ & $4.7 \%$ & $0.8 \%$ & $-1.1 \%$ & $0.3 \%$ & $0.4 \%$ & $0.4 \%$ & $1.4 \%$ & $1.3 \%$ \\
\hline 2011 & $1,573.2$ & $6.1 \%$ & $-5.3 \%$ & $-7.0 \%$ & $-7.4 \%$ & $-4.5 \%$ & $-3.6 \%$ & $-3.0 \%$ & $-1.5 \%$ & $-1.4 \%$ & \\
\hline 2012 & $1,668.9$ & $-15.5 \%$ & $-12.9 \%$ & $-11.4 \%$ & $-6.9 \%$ & $-5.5 \%$ & $-4.5 \%$ & $-2.6 \%$ & $-2.2 \%$ & & \\
\hline 2013 & $1,409.5$ & $-10.2 \%$ & $-9.3 \%$ & $-3.9 \%$ & $-2.8 \%$ & $-2.1 \%$ & $-0.2 \%$ & $-0.2 \%$ & & & \\
\hline 2014 & $1,266.1$ & $-8.5 \%$ & $-0.6 \%$ & $-0.1 \%$ & $0.1 \%$ & $1.9 \%$ & $1.6 \%$ & & & & \\
\hline 2015 & $1,158.9$ & $8.0 \%$ & $4.3 \%$ & $3.1 \%$ & $4.7 \%$ & $3.7 \%$ & & & & & \\
\hline 2016 & $1,251.9$ & $0.7 \%$ & $0.7 \%$ & $3.6 \%$ & $2.7 \%$ & & & & & & \\
\hline 2017 & $1,260.4$ & $0.7 \%$ & $5.1 \%$ & $3.4 \%$ & & & & & & & \\
\hline 2018 & $1,268.9$ & $9.7 \%$ & $4.7 \%$ & & & & & & & & \\
\hline 2019 & $1,391.8$ & $0.0 \%$ & & & & & & & & & \\
\hline
\end{tabular}

For a retail investor, investment in gold is generally considered as a long-term investment. Nevertheless, it was possible to achieve any return of investment within only one year, in 16 out of the last 20 years. The same was true for the investment period of 2 or 3 years. In the longer term, there was an increase in the price of gold, offsetting the possible loss (highlighted in gray in Table 3) if the investor was unlucky and bought the gold in the year when its price was at its highest (eg 2010-2013).

The average appreciation of gold with an investment period of only one year has been almost $9.2 \%$ p.a. since 2000 (the last 20 years). Even in the case of longer-term investment, the average annual return on this gold investment remained broadly unchanged, and in all cases exceeded $9 \%$ p.a.: 
Table 4. Average appreciation of gold in 1 - 10 years since 2000 (p. a.).

\begin{tabular}{cccccccccc}
\hline \multicolumn{10}{c}{ Length of investment (years) } \\
$\mathbf{1}$ & $\mathbf{2}$ & $\mathbf{3}$ & $\mathbf{4}$ & $\mathbf{5}$ & $\mathbf{6}$ & $\mathbf{7}$ & $\mathbf{8}$ & $\mathbf{9}$ & $\mathbf{1 0}$ \\
\hline $9.16 \%$ & $9.51 \%$ & $9.52 \%$ & $9.52 \%$ & $9.59 \%$ & $9.65 \%$ & $9.64 \%$ & $9.77 \%$ & $9.99 \%$ & $10.22 \%$ \\
\hline
\end{tabular}

In the case of investment in gold over a longer period, the appreciation has always been positive over the last 20 years ranging from an average of $3.3 \%$ p.a. per year to $18.0 \%$ p.a. if the investor started investing in 2001:

Table 5. Appreciation of gold in 11 - 20 years since 2000 (p. a.).

\begin{tabular}{lccrrrrrrrrl}
\hline \multirow{2}{*}{ Year } & Price & \multicolumn{1}{c}{ Length of investment (years) } \\
& & $\mathbf{1 1}$ & $\mathbf{1 2}$ & $\mathbf{1 3}$ & $\mathbf{1 4}$ & $\mathbf{1 5}$ & $\mathbf{1 6}$ & $\mathbf{1 7}$ & $\mathbf{1 8}$ & $\mathbf{1 9}$ & $\mathbf{2 0}$ \\
\hline 2000 & 279.3 & $17.0 \%$ & $16.1 \%$ & $13.3 \%$ & $11.4 \%$ & $10.0 \%$ & $9.8 \%$ & $9.3 \%$ & $8.8 \%$ & $8.8 \%$ & $8.4 \%$ \\
2001 & 271.2 & $18.0 \%$ & $14.7 \%$ & $12.6 \%$ & $10.9 \%$ & $10.7 \%$ & $10.1 \%$ & $9.5 \%$ & $9.5 \%$ & $9.0 \%$ & \\
2002 & 310.1 & $14.8 \%$ & $12.4 \%$ & $10.7 \%$ & $10.5 \%$ & $9.8 \%$ & $9.2 \%$ & $9.2 \%$ & $8.7 \%$ & & \\
2003 & 363.8 & $12.0 \%$ & $10.1 \%$ & $10.0 \%$ & $9.3 \%$ & $8.7 \%$ & $8.7 \%$ & $8.2 \%$ & & & \\
2004 & 409.5 & $9.9 \%$ & $9.8 \%$ & $9.0 \%$ & $8.4 \%$ & $8.5 \%$ & $7.9 \%$ & & & & \\
2005 & 445.0 & $9.9 \%$ & $9.1 \%$ & $8.4 \%$ & $8.5 \%$ & $7.9 \%$ & & & & \\
2006 & 604.3 & $6.9 \%$ & $6.4 \%$ & $6.6 \%$ & $6.1 \%$ & & & & & & \\
2007 & 696.4 & $5.6 \%$ & $5.9 \%$ & $5.5 \%$ & & & & & & & \\
2008 & 872.4 & $4.3 \%$ & $4.0 \%$ & & & & & & & & \\
2009 & 973.7 & $3.3 \%$ & & & & & & & & &
\end{tabular}

As in the shorter investment horizon, the average return of the gold investment was always around $9 \%$ p.a., the highest was an average of $10.2 \%$ p.a. if investing for 11 years:

Table 6. Average appreciation of gold in 11 - 20 years since 2000 (p.a.).

\begin{tabular}{lccccccccc}
\hline \multicolumn{1}{c}{ Length of investment (years) } \\
\hline 11 & $\mathbf{1 2}$ & $\mathbf{1 3}$ & $\mathbf{1 4}$ & $\mathbf{1 5}$ & $\mathbf{1 6}$ & $\mathbf{1 7}$ & $\mathbf{1 8}$ & $\mathbf{1 9}$ & $\mathbf{2 0}$ \\
\hline $10.2 \%$ & $9.8 \%$ & $9.5 \%$ & $9.3 \%$ & $9.3 \%$ & $9.2 \%$ & $9.1 \%$ & $9.0 \%$ & $8.9 \%$ & $8.4 \%$ \\
\hline
\end{tabular}

\section{Discussion}

Most people use bank products - savings accounts or various funds - to save or invest. While the older generation is conservative and does not make much use of modern banking technology, the young generation takes the bank account and credit card for granted. Nevertheless, this young generation has some reserves in financial literacy (Hedvičáková et al. 2017). It turns out that, instead of actively seeking investment opportunities, young pupils and students only increase consumption spending. They then use pocket money to buy extra goods, and in fact, no one discourages them and prepares them for the "real world", although this can be beneficial for both students and educational institutions (eg universities) in many areas. (Novotná 2019) The style of our time living here and now is more than encouraging.

In addition to merchants, banks also benefit from these purchases. As cash payments are still popular, they charge considerable processing fees and, despite significant cash processing costs (Král 2017; Král and Hájek 2017), they make billions of profits (Finance 2019). Therefore, banking institutions will by no means offer investors alternative investment opportunities, they will always prefer to sell their products - mutual funds, savings accounts, perhaps even buying real estate on credit. 
These products are often disadvantageous for investors. For example, in savings accounts, the appreciation rate usually does not exceed the level of inflation. In reality, people lose the value of their savings every year by saving on bank accounts. In the case of investment funds, there may be an appreciation rate that is higher than the inflation rate, but a frequent disadvantage is that investors have to fully trust the bank and often does not even know exactly what it is investing in. The final profit may also be influenced by the exchange rate, which allows further speculation, eg in the period of the end of foreign exchange interventions of Czech National Bank, companies assumed an apreciation of CZK, therefore, the volume of loans denominated in euro compared to loans denominated in CZK etc (Mačí et al. 2017).

In the case of investment in physical gold, this situation cannot occur, moreover, unlike most other investments (stocks, virtual currencies), it is a "net" investment that does not produce any carbon emissions (Baur and Oll 2019). Equally worth mentioning is the comparison of gold and bitcoin, which is said to be virtual gold. So if an investor prefers virtual currency instead of physical gold, he does not invest in virtual gold, as these two "investments" show quite different tendencies. Bitcoin, for example, is much more volatile and, in contrast to gold, responds to financial market events quite the opposite (Klein et al. 2018).

\section{Conclusions}

In many economic and banking books we can read that investment in real assets is a long-term investment. The long-term investment horizon is generally longer than five years and is therefore comparable to the investment horizon for shares or different funds. Investing in a variety of funds, whether equity or bond or otherwise, is generally encouraged, as opposed to investing in precious metals. Political representativeness tells people to save for retirement savings, banks offer their clients various equity, bond, real estate or other funds... However, investments in precious metals are not mostly actively recommended nor by politicians (government representatives) nor banks.

The question remains why this is the case, as the price of gold has risen by about five times over the past 20 years. By comparison, the average closing value of the Dow Jones stock index was about $\$ 10,730$ in 2000, and about \$26,500 in 2019 (Macrotrends 2019b). Compared to gold, therefore, the appreciation of this index was about half. For ordinary people who do not have enough information or rely on social networks marketing information (Hruška and Pásková 2018) and have to rely on the advice of others, this situation is sad.

Of course, it can be argued that no retail investor can buy gold at a middle price, and the price of buying and selling varies considerably, storage costs are not zero, etc., as well as the price of other companies' shares rising much more than average stock indices. This discussion could, therefore, go in many ways, but the point remains indisputable: the average closing price of gold has increased much more than average closing price of stock indices over the past twenty years. So if someone has bought physical gold since 2000, he made a "mistake" only if he bought it when everyone knew the gold price was at historical highs.

Acknowledgments: This paper is supported by specific project No. 2103 "Investment evaluation within concept Industry 4.0" at Faculty of Informatics and Management, University of Hradec Kralove, Czech Republic.

\section{References}

Baur G. Dirk, and Oll Josua. 2019. From financial to carbon diversification - The potential of physical gold. Energy Economics: 81, 1002-1010. https://doi.org/10.1016/j.eneco.2019.06.003

Finance. 2019. Kolik jednotlivé banky odvedly na dividendách?. Available online: https://firmy.finance.cz/525051zisky-a-dividendy-bank/ (accessed on 29 December 2019).

Green Timothy. 2007. The Ages of gold: Mines, markets, merchants and goldsmiths from Egypt to Troy, Rome to Byzantium, and to Venice to the space age. London: GFMS Limited.

Gold Hub. 2019. Gold mine production. Available online: https://www.gold.org/goldhub/data/historical-mineproduction (accessed on 28 December 2019). 
Hedvičáková Martina, Svobodová Libuše, Dittrichová Jaroslava, and Král Martin. 2017. Financial Literacy and Money Management of the Pupils in the Czech Education System. Paper presented at the 8th International Scientific Conference on Finance and Performance of Firms in Science, Education and Practice, Zlín, Czech Republic, April 26-27, pp. 244-259. Available online: https://digilib.k.utb.cz/bitstream/handle/10563/43685/Proceedings8th\%20International\%20Scientific\%20Conferecne\%202017.pdf?sequence=1 (accessed on 29 December 2019).

Hruška Jan, and Pásková Martina. 2018. How do the National Tourism Organizations use the social media? E+M Ekonomie a Management, 21(4), 226-240. https://doi.org/10.15240/tul/001/2018-4-015.

Klein Tony, Thu Hein Pham, and Walther Thomas. 2018. Bitcoin is not the New Gold - A comparison of volatility, correlation, and portfolio performance. International Review of Financial Analysis: 59, 105-116. https://doi.org/10.1016/j.irfa.2018.07.010

Král Martin. (2017). Modelling of Savings in Decentralised Cash Processing Costs in the Czech Republic. Paper presented at the 15th International Scientific Conference on Hradec Economic Days 2017, Hradec Králové, Czech Republic, January-February 31-1, pp. 478-485. Available online: https://uni.uhk.cz/hed/site/assets/files/1046/proceedings_2017_1.pdf (accessed on 28 December 2019).

Král Martin, and Hájek Ladislav. (2017). Modelling and Optimization Cash Processing Costs in the Czech Republic. Paper presented at the 8th International Scientific Conference on Finance and Performance of Firms in Science, Education and Practice, Zlín, Czech Republic, April 26-27, pp. 420-433. Available online: https://digilib.k.utb.cz/bitstream/handle/10563/43685/Proceedings-

8th\%20International\%20Scientific\%20Conferecne\%202017.pdf?sequence=1 (accessed on 28 December 2019).

Macrotrends. 2019a. Gold Prices - 100 Year Historical Chart. Available online: https://www.macrotrends.net/1333/historical-gold-prices-100-year-chart (accessed on 28 December 2019).

Macrotrends. 2019b. Dow Jones - 10 Year Daily Chart. Available online: https://www.macrotrends.net/1358/dowjones-industrial-average-last-10-years (accessed on 28 December 2019).

Mačí Jan, Hyblerová Šárka, and Ohm Jan. (2017). Corporate Loans and Czexit on Euro-Koruna. Paper presemted at the 13th International Conference on Liberec Economic Forum, Liberec, Czech Republic, September 1113, pp. 353-361. Available online: http://lef.tul.cz/assets/lef-2017.pdf (accessed on 28 December 2019).

Novotná Lucie. (2019). Student - University - Employer Trilateral Relationship: A Case Study. Paper presented at the 6th SWS International Scientific Conference on Arts and Humanities 2019, Florence, Italy, October 2224, pp. 77-84.

Our World in Data. 2019. Gold Production. Available online: https://ourworldindata.org/grapher/goldproduction (accessed on 28 December 2019).

Rejnuš Oldřich. (2016). Prediction of Future Development of the World Economy under Conditions of Negative Interest Rates. Paper presented at the 13th International Scientific Conference European Financial Systems, Brno, Czech Republic, June 27-28, pp. 646-653. Available online: https://is.muni.cz/do/econ/sborniky/2016/EFS2016-Proceedings_final_September_19_final.pdf (accessed on 28 December 2019).

Soukal Ivan, and Draessler Jan. 2012. Consumer desired price modeling - case study on the RCBS market. In Procedia Social and Behavioral Sciences. Elsevier Ltd., Vol. 62, pp. 916-920. https://doi.org/10.1016/j.sbspro.2012.09.155

Svobodová Libuše, and Hedvičáková Martina. 2015. The Payment Cards and their Utilization in the Czech Republic. Paper presented at the 12th International Scientific Conference European Financial Systems, Brno, Czech Republic, June 18-19, pp. 587-595. Available online: https://is.muni.cz/do/econ/sborniky/2015/EFS_2015_proceedings.pdf (accessed on 28 December 2019).

World Bank. 2019. Population, total. Available online: https://data.worldbank.org/indicator/SP.POP.TOTL (accessed on 28 December 2019).

Worthington C. Andrew, and Pahlavani Mosayeb. 2007. Gold investment as an inflationary hedge: cointegration evidence with allowance for endogenous structural breaks. Applied Financial Economics Letters: 3, $259-262$. https://doi.org/10.1080/17446540601118301 